\title{
Analisis Moderasi Mediasi Hubungan Arus Kas-Investasi, CSR, dan Biaya Agensi
}

Sri Rahmah Putri Bestari

Kiswanto

Universitas Negeri Semarang

\section{ARTICLE INFO}

Keywords:

Agency Costs, Cash Flow, CSR, Investation .

\begin{abstract}
This study aims to examine the factors that affect investment in manufacturing companies in Indonesia by using 3 variables consisting of 1 independent variable that is cash flow, 1 moderation variable that is CSR and 1 mediation variable that is agency cost. The population in this study is a manufacturing company listed on the Indonesia Stock Exchange (BEI) during the period 2011-2016 which amounted to 149 companies. The sample used in this study amounted to 41 companies selected using purposive sampling technique. Data were analyzed using classical assumption test, simple regression analysis and regression analysis with moderating mediating (modmed) variable SPSS 23. The results showed that cash flow has no effect on investment, CSR proved to be a moderate variable of the relationship between cash flow to investment and agency costs able to mediate the moderate effects of CSR. The conclusion of this research is that cash flow can not be a factor affecting investment, CSR can be a moderating variable strengthening the relationship between cash flow to investment and agency cost can be a mediation variable of moderation effect of CSR.
\end{abstract}

\section{ABSTRAK}

Penelitian ini bertujuan untuk menguji faktor-faktor yang mempengaruhi investasi pada perusahaan manufaktur di Indonesia dengan menggunakan 3 variabel yang terdiri dari 1 variabel independen yaitu arus kas, 1 variabel moderasi yaitu CSR dan 1 variabel mediasi yaitu biaya agensi. Populasi dalam penelitian ini adalah perusahaan manufaktur yang terdaftar di Bursa Efek Indonesia (BEI) selama periode 2011-2016 yang berjumlah 149 perusahaan. Sampel yang digunakan dalam penelitian ini berjumlah 41 perusahaan yang dipilih menggunakan teknik purposive sampling. Data dianalisis menggunakan uji asumsi klasik, analisis regresi sederhana dan analisis regresi dengan variabel moderating mediating (modmed) SPSS 23. Hasil penelitian menunjukkan bahwa arus kas tidak berpengaruh terhadap investasi, CSR terbukti menjadi variabel moderasi hubungan antara arus kas terhadap investasi dan biaya agensi mampu memediasi efek moderat CSR. Simpulan dari penelitian ini yaitu arus kas tidak dapat menjadi faktor yang mempengaruhi investasi, CSR dapat menjadi variabel moderasi yang memperkuat hubungan antara arus kas terhadap investasi dan biaya agensi dapat menjadi variabel mediasi efek moderasi CSR.

\section{How to Cite:}

Bestari, Sri Rahmah Putri dan Kiswanto. Analisis Moderasi Mediasi Hubungan Arus Kas-Investasi, CSR, dan Biaya Agensi. Jurnal Ilmiah Wahana Akuntansi, 14 (1), 33-48. https://doi.org/10.21009/wahana.014.1.3. 
Sri Rahmah Putri Bestari dan Kiswanto/ Jurnal Ilmiah Wahana Akuntansi, 14 (1) 2019, 33-48

\section{PENDAHULUAN}

Investasi diartikan sebagai pengeluaran pada saat sekarang untuk membeli aktiva riil (tanah, rumah, mobil dan sebagainya) atau aktiva keuangan dengan tujuan untuk mendapatkan penghasilan yang lebih besar di masa yang akan datang, selanjutnya dikatakan investasi adalah aktivitas yang berkaitan dengan usaha penarikan sumber-sumber (dana) yang dipakai untuk mengadakan barang modal pada saat sekarang, dengan barang modal itu akan dihasilkan aliran produk baru di masa yang akan datang dan investasi jangka panjang adalah komitmen untuk mengeluarkan dana sejumlah tertentu pada saat sekarang untuk memungkinkan perusahaan menerima manfaat di waktu yang akan datang (Haming \& Basalamah, 2010).

Pergerakan pasar modal mencerminkan kondisi ekonomi sebuah negara dan pergerakan pasar modal dicerminkan oleh perilaku investor dalam pengambilan keputusan investasi (Masrurun \& Yanto, 2015). Di pasar yang tidak sempurna, keputusan investasi perusahaan bergantung pada situasi keuangannya (Samet \& Jarboui, 2017). Jadi, keputusan investasi perusahaan tidak bisa dilakukan secara sembarangan dan perusahaan harus melihat bagaimana kondisi keuangan perusahaan mencukupi atau tidak. Jika perusahaan menginvestasikan sejumlah besar uang tunai, pengeluarannya juga meningkat dan ini menyebabkan kerugian yang cukup besar atau kebangkrutan di bawah kondisi ekonomi yang tidak cocok (Shamsuddini, 2017). Perusahaan yang memiliki kesempatan investasi tinggi membutuhkan dana eksternal yang besar untuk melakukan ekspansi (Rahayuningsih,2013). Jika peserta pasar modal menghadapi

ketidakpastian prospek masa depan perusahaan, biaya modal eksternal seringkali melebihi biaya pembiayaan internal (Samet dan Jarboui,2017). Mereka percaya bahwa sebuah perusahaan berkinerja baik mampu mencapai keuntungan maksimal dan memiliki prospek ke depan (Hanifah \& Khafid, 2016). Artinya, tingkat pengembalian yang tinggi merupakan salah satu ukuran keberhasilan perusahaa memperoleh keuntungan dalam jangka panjang. Imbal balik yang diperoleh investor sangat penting karena menentukan keberlanjutan perusahaan.

Pasar modal merupakan media yang sangat efektif untuk dapat menyalurkan dan menginvestasikan dana yang berdampak produktif dan menguntungkan investor (Fistriyani \& Kusmuriyanto, 2015). Menurut (Tandelilin, 2010), pengertian pasar modal adalah pertemuan antara pihak yang membutuhkan dana dengan cara memperjualbelikan sekuritas. Industri manufaktur merupakan industri yang mendominasi perusahaan-perusahaan yang terdaftar di Bursa Efek Indonesia (Janalis, 2015). Artinya, industri manufaktur merupakan industri yang kegiatan 
operasionalnya sebagian besar mengandalkan modal dari investor.

Hingga kini tahun 2017, manufaktur masih menjadi sektor penyumbang investasi terbesar di Indonesia, dengan kontribusi 55\% pada 2016. Berdasarkan data Badan Koordinasi Penanaman Modal (BKPM), penanaman modal asing (PMA) di industri manufaktur naik dari US\$ 11,8 miliar menjadi US\$ 16,7 miliar, sedangkan penanaman modal dalam negeri (PMDN) dari Rp 89 triliun menjadi Rp 106,8 triliun (Rahajeng dan Syukra, 2017). Pengamat ekonomi Faisal Basri

mengatakan, pengembangan industri manufaktur merupakan solusi untuk menyelesaikan persoalan ekonomi di Indonesia. Sebab, majunya industri manufaktur akan berdampak luas mulai dari perdagangan, penyerapan tenaga kerja, perpajakan hingga pertanian (Deny,2017).

Realita yang ada di lapangan sangat berbeda dengan harapan, karena industri manufaktur di Indonesia kini "dikeroyok" masalah hampir dari segala penjuru. Industri padat karya dalam negeri ini seperti tergencet oleh ketidakberpihakan regulasi, terbelit masalah permodalan, infrastruktur, dan tentu saja persoalan ketenagakerjaan atau buruh. Sementara dari faktor eksternal, krisis finansial di Eropa dan Amerika Serikat nyatanyata telah memukul kinerja ekspor produk manufaktur, dan di saat yang sama juga menghambat produksi lantaran mayoritas bahan baku dan bahan penolong masih tergantung dengan produk impor (Harian Neraca Ekonomi,2018).

Masalah paling pokok yang dihadapi perusahaan yang bergerak di bidang apapun termasuk pada industri manufaktur adalah tentang kebutuhan dana. Salah satu yang mendukung ketersediaan dana atau modal yaitu dengan adanya kas sebagai sumber dana internal perusahaan. Perusahaan yang mengelola sumber dana dalam hal ini kas sebaik-baiknya menunjukkan bahwa perusahaan memiliki kinerja yang baik (Janalis, 2015).

Penelitian yang dilakukan oleh Janalis (2015) dan Melander (2009) menunjukkan hasil bahwa arus kas berpengaruh positif terhadap investasi. Berbeda dengan penelitian tersebut, penelitian yang dilakukan Atmawati (2013) dan Benardi (2010) menunjukkan bahwa arus kas tidak berpengaruh terhadap investasi.

Hubungan antara arus kas dengan investasi dapat mengarah pada asimetri

informasi. Asimetri informasi antara pemegang saham dan CEO umumnya dianggap sebagai masalah prinsipal dan agen. Menurut Jensen (1986), ketika fungsi tujuan manajemen tidak mencerminkan kepentingan pemegang saham, inefisiensi investasi dapat terjadi karena konflik keagenan antara pemegang saham dan CEO. Oleh karena itu CSR sebagai moderasi hubungan antara penegluaran investasi dan dana internal perusahaan. Kinerja CSR dapat membantu 
perusahaan mengatasi masalah keagenan. Akses modal yang lebih baik didorong oleh penurunan biaya agen (Samet \& Jarboui, 2017).

Tujuan penelitian ini adalah untuk menguji secara empiris faktor-faktor yang mempengaruhi investasi. Orisinalitas penelitian ini terletak pada penggunaan variabel moderasi dan variabel mediasi dalam satu model regresi belum ada di Indonesia. Penelitian ini menggunakan teori keagenan, teori packing order dan teori sinyal.

\section{TELAAH PUSTAKA DAN HIPOTESIS}

Teori keagenan dicetuskan pertama kali oleh Jensen dan Meckeling (1976) merupakan teori yang menjelaskan hubungan antara pemegang saham sebagai principals dan manajemen sebagai agen. Manajemen merupakan pihak yang dikontrak oleh pemegang saham untuk bekerja demi kepentingan pemegang saham. Bentuk pertanggungjawaban tersebut dapat berupa laporan keuangan. Laporan keuangan dapat mencerminkan kondisi perusahaan bagaimana pertumbuhan keuangan perusahaan karena agen bertanggungjawab atas kesejahteraan pemegang saham. Jadi, keputusan apapun yang akan diambil pun harus sesuai dengan keputusan bersama. Dengan demikian, jika konflik dapat diatasi akan dapat meminimalkan timbulnya biaya agensi.

Penamaan Pecking Order Theory dilakukan Myers (1984). Pecking Order
Theory menjelaskan bahwa pendanaan dari dalam perusahaan lebih didahulukan daripada sumber pendanaan dari luar perusahaan.

Pecking Order Theory menggambarkan sebuah tingkatan dalam pencarian dana perusahaan yang menunjukkan bahwa perusahaan lebih membiayai investasi dan mengimplementasikannya sebagai peluang pertumbuhan. Arus kas sebagai dana internal perusahaan sebaiknya dimaksimalkan untuk pembiayaan eksternal perusahaan seperti investasi.

Menurut Akrelof (1970), teori signalling menjelaskan bagaimana perusahaan memberikan sinyal kepada pengguna laporan keuangan. Teori sinyal menjelaskan tentang dorongan perusahaan dalam memberikan informasi laporan keuangan kepada pihak eskternal. Teori signalling menekankan pentingnya pengungkapan Corporate Social

Responsibility dengan harapan dapat meningkatkan reputasi dan nilai perusahaan di masa yang akan datang.

Laporan arus kas adalah laporan keuangan yang mencerminkan arus kas masuk, arus kas keluar dan perubahan bersih arus kas selama satu periode. Menurut Janalis (2015) manajemen kas yang efisien membutuhkan kas yang tersedia untuk operasional atau dalam investasi jangka panjang. Semakin besar jumlah kas yang ada dalam perusahaan berarti semakin kecil resiko perusahaan untuk tidak dapat memenuhi kewajiban finansialnya. Hal utama yang mendasar dalam mengatur arus 
kas adalah memahami dengan jelas fungsi dana atau uang yang dimiliki, disimpan dan diinvestasikan. Arus kas merupakan sumber pendanaan internal bagi perusahaan dan para manajer cenderung untuk membuat keputusan investasi dengan mengandalkan dana internalnya terlebih dahulu.

Hubungan antara variabel arus kas dan variabel investasi dilandasi oleh teori pecking order, dimana sumber pendanaan dari dalam perusahaan lebih didahulukan daripada sumber pendanaan dari luar perusahaan. Semakin besar arus kas yang dimiliki perusahaan maka semakin besar pula investasi yang dilakukan oleh perusahaan. Penelitian sebelumnya yang mendukung adalah penelitian yang dilakukan oleh Janalis (2015) dan Melander (2009) yang menyatakan bahwa arus kas berpengaruh positif terhadap investasi.

\section{$\mathrm{H}_{1}$ : Arus kas berpengaruh positif terhadap investasi.}

Masalah paling pokok yang dihadapi perusahaan yang bergerak di bidang apapun termasuk pada industri manufaktur adalah tentang kebutuhan dana. Salah satu yang mendukung ketersediaan dana atau modal yaitu dengan adanya kas sebagai sumber dana internal perusahaan. Perusahaan yang mengelola sumber dana dalam hal ini kas

sebaik-baiknya menunjukkan bahwa perusahaan memiliki kinerja yang baik (Janalis, 2015). Namun agar arus kas perusahaan tetap seimbang, maka pembiayaan eksternal dapat menjadi alternatif pengembangan perusahaan. Pembiayaan eksternal perusahaan dilakukan melalui penjualan saham perusahaan kepada calon investor di pasar modal. Oleh karena itu, agar dapat menarik minat investor dan kemudahan untuk mendapatkan modal, perusahaan harus meningkatkan kinerjanya agar investor mau berinvestasi di perusahaannya. Meningkatkan kinerja perusahaan dapat diwujudkan melalui Corporate Social Responsibility (CSR).

Secara umum Corporate Social Responsibility dapat diartikan sebagai suatu mekanisme perusahaan untuk secara sadar mengintegrasikan sebuah perhatian terhadap lingkungan sosial ke dalam operasi dan interaksinya dengan pemangku kepentingan (stakeholder), yang melampaui tanggung jawab sosial di bidang hukum (Munawaroh, 2014).

Segala jenis kegiatan usaha terutama yang bergerak dalam pemanfaatan sumber daya baik secara langsung maupun tidak langsung sudah pasti memberikan dampak terhadap lingkungan sekitar, seperti masalah pencemaran lingkungan, masalah tenaga kerja dan masalah terkait produk yang dihasilkan. Hal ini menunjukkan bahwa perusahaan manufaktur memiliki andil yang cukup besar dalam permasalahan lingkungan dan sosial (Yuliawati \& Sukirman, 2015). Hal ini yang menjadi pertimbangan bahwa CSR dapat menjadi moderator hubungan arus kas dan investasi karena dengan nilai lingkungan yang 
baik akan dapat menarik minat investor untuk berinvestasi di perusahaan tersebut.

Pengungkapan Corporate Social Responsibility (CSR ) ini dilandasi oleh teori signalling yang menjelaskan bahwa perusahaan harus memberikan sinyal kepada pengguna laporan keuangan. Perusahaan melakukan pengungkapan CSR dengan harapan dapat meningkatkan reputasi dan nilai perusahaan di masa yang akan datang (Anggitasari, 2012). Nandy dan Lodh (2012) berpendapat bahwa perusahaan dengan nilai lingkungan yang lebih tinggi mendapatkan kontrak pinjaman yang lebih baik daripada perusahaan dengan nilai lingkungan yang lebih rendah.

\section{H2: CSR memoderasi pengaruh arus kas terhadap investasi}

Hubungan keagenan merupakan suatu kontrak dimana satu atau lebih orang (prinsipal) memerintah orang lain (agen) untuk melakukan suatu jasa atas nama prinsipal serta memberi wewenang kepada agen membuat keputusan yang terbaik bagi prinsipal. Hubungan keagenan ini dapat mengarah pada kondisi ketidakseimbangan informasi (asimetri informasi) karena manajer berada pada posisi yang memiliki informasi yang lebih banyak tentang perusahaan dibandingkan dengan pemilik saham. Asumsi bahwa manajer memiliki lebih banyak informasi tentang perusahaan mendorongnya untuk menyembunyikan beberapa informasi dari pemilik saham untuk memaksimalkan kepentingan diri sendiri sehingga memicu timbulnya konflik.

Terjadinya konflik antara principal dan agen tersebut yang menimbulkan adanya biaya keagenan (agency costs) (Herlina). Untuk mengurangi konflik tersebut perlu adanya pencegahan yang dilakukan yaitu dengan melakukan kegiatan CSR. Ketika keterlibatan pemangku kepentingan efektif maka biaya agensi dapat berkurang karena principal merasa bahwa agen sudah bertindak sesuai dengan keinginannya. Biaya keagenan merupakan biaya yang dikeluarkan perusahaan untuk mencapai titik temu atas perbedaan kepentingan antara agen dan principal (Hendro \& Wardhani, 2016).

Untuk menghindari pengeluaran yang sia -sia, pemegang saham memantau aktivitas para manajer. Kegiatan pemantauan ini

meningkatkan biaya pemantauan dan meningkatkan biaya agensi (Guizani, 2017). Astuti dan Rahman (2015) berpendapat bahwa agency costs yang semakin tinggi mencerminkan bahwa semakin kompleks konflik keagenan di dalam perusahaan.

Timbulnya biaya agensi ini dilandasi oleh teori keagenan yang menjelaskan bahwa hubungan keagenan merupakan suatu kontrak dimana satu atau lebih orang (principal) memerintah orang lain (agen) untuk melakukan suatu jasa atas nama principal serta memberi wewenang kepada agen membuat keputusan yang terbaik bagi principal. Jika kedua belah pihak tersebut mempunyai tujuan 
yang sama untuk memaksimumkan nilai perusahaan, maka diyakini agen akan bertindak dengan cara yang sesuai dengan kepentingan principal. Tetapi jika tidak maka akan terjadi konflik yang mengakibatkan munculnya biaya agensi.

Menurut Jensen (1986) ketika fungsi tujuan manajemen tidak mencerminkan kepentingan pemegang saham, inefisiensi investasi dapat terjadi karena konflik keagenan antara pemilik dan pemegang saham.

Harjoto dan Jo (2011) berpendapat bahwa perusahaan menggunakan mekanisme tata kelola bersamaan dengan keterlibatan CSR, untuk mengurangi konflik antara para pemangku kepentingan dan pemangku kepentingan non investasi. Cheng (2014) mengungkapkan bahwa perusahaan dengan kinerja CSR yang baik memiliki akses modal yang lebih baik karena biaya agen yang berkurang akibat keterlibatan pemangku kepentingan yang lebih efektif.

\section{$\mathrm{H}_{3}$ : Biaya agensi memediasi efek moderat CSR}

\section{METODE PENELITIAN}

Penelitian ini merupakan penelitian kuantitatif dengan menggunakan data sekunder, yaitu data penelitian yang diperoleh dan dikumpulkan peneliti dari berbagai sumber yang sudah ada. Desain penelitian ini adalah studi pengujian hipotesis (hipothesis study) yang bertujuan untuk menganalisa, mendeskripsikan, dan mendapatkan bukti empiris pola hubungan antara arus kas terhadap investasi yang di moderasi CSR dan di mediasi biaya agensi.

Populasi dalam penelitian ini adalah Perusahaan Manufaktur yang terdaftar di Bursa Efek Indonesia periode tahun 20112016, yang berjumlah 149 perusahaan. Sampel yang digunakan dalam penelitian ini berjumlah 41 perusahaan yang dipilih dengan menggunakan teknik purposive sampling.

Kriteria pemilihan sampel dapat dilihat pada Tabel 1.

\section{Tabel 1}

\section{Kriteria Pemilihan Sampel}

\begin{tabular}{|l|r|}
\hline \multicolumn{1}{|c|}{ Kriteria Sampel } & \multicolumn{1}{|c|}{$\begin{array}{c}\text { Jumlah } \\
\text { Perusahaan }\end{array}$} \\
\hline $\begin{array}{l}\text { Perusahaan Manufaktur yang } \\
\text { terdaftar di BEI tahun 2011- } \\
2016\end{array}$ & 149 \\
\hline $\begin{array}{l}\text { Tidak tersedia laporan tahunan } \\
\text { lengkap selama tahun 2011- } \\
\text { 2016 }\end{array}$ & \\
\hline $\begin{array}{l}\text { Tersedia laporan tahunan } \\
\text { lengkap selama tahun 2011- } \\
\text { 2016 }\end{array}$ & \\
\hline $\begin{array}{l}\text { Tidak memiliki data yang } \\
\text { lengkap terkait dengan variabel } \\
\text { yang digunakan dalam }\end{array}$ & \\
penelitian & \\
\hline Sampel Penelitian & \\
\hline Total Unit Analisis (2011- \\
2016)
\end{tabular}

Sumber: Data Diolah Penulis, Tahun 2018

Definisi operasional dan pengukuran variabel pada penelitian ini disajikan pada Lampiran 1 dari penelitian ini.

Data sekunder dalam penelitian ini dikumpulkan menggunakan teknik dokumentasi yang dapat diambil melalui media atau perantara baik dalam bentuk arsip 
Sri Rahmah Putri Bestari dan Kiswanto/ Jurnal Ilmiah Wahana Akuntansi, 14 (1) 2019, 33-48

maupun dokumen tertentu. Teknik dibawah $\alpha=0,05$ sehingga data dikatakan dokumentasi digunakan untuk mengumpulkan tidak normal. Data dapat dikatakan normal seluruh data sekunder yang termasuk dalam apabila nilai Asymp. Sig lebih dari 0,05, oleh sampel penelitian berupa laporan keuangan karena itu untuk mendapatkan data tahunan perusahaan manufaktur yang telah berdistribusi normal dilakukan metode diterbitkan oleh Bursa Efek Indonesia (BEI) periode $2011-2016$.

Metode analisis yang digunakan dalam penelitian ini adalah analisis statistik deskriptif dan analisis statistik inferensial dengan SPSS 23.

\section{HASIL DAN PEMBAHASAN}

Hasil analisis statistik deskriptif disajikan pada Tabel 2 di bawah ini.

Tabel 2

Statistik Deskriptif

\begin{tabular}{lrrrr}
\hline Variabel & Minimum & Maksimum & Mean & Std. Deviation \\
\hline Investasi & $-0,999$ & 10,482 & 0,2772 & 0,932806 \\
& & & 8 & \\
Arus kas & - & 738,236 & - & 151152,3635 \\
& 2370735,5 & & 9641,1 & 11 \\
& 38 & & 9382 & \\
CSR & 0,110 & 0,440 & 0,2120 & 0,086951 \\
& & & 1 & \\
Biaya & 0,011 & 2,559 & 0,1771 & 0,207559 \\
agensi & & & 4 & \\
\hline
\end{tabular}

Sumber: Data Diolah Penulis, Tahun 2018

Analisis statistik inferensial yang digunakan untuk menguji hipotesis meliputi uji asumsi klasik, analisis regresi sederhana dan analisis regresi dengan variabel moderating mediating (modmed) dengan tingkat signifikan sebesar 5\%.

Uji normalitas menggunakan uji Test Kolmogorov-Smirnov dengan data asli memberikan nilai probabilitas 0,000 jauh

transformasi data menggunakan rumus SQRT dan LN.

Data yang ditransform tersebut kemudian di uji normalitas kembali berdasarkan nilai residu dengan menggunakan uji Kolmogorov-Smirnov dan menghasilkan nilai sebesar 0,496 jauh diatas $\alpha=0,05$. Jadi, dapat disimpulkan bahwa data residual berdistribusi normal.

Uji autokorelasi menunjukkan nilai DW 1,745 lebih besar dari batas (dU) 1,7364 dan kurang dari $4-1,7364(4-\mathrm{dU})$ yaitu 1,7364< $1,745<2,264$. Maka dapat disimpulkan bahwa tidak terdapat autokorelasi.

Uji multikolinieritas dilihat dari hasil perhitungan nilai Tolerance menunjukkan tidak ada variabel yang memiliki nilai Tolerance kurang dari 0,10 yang berarti tidak ada korelasi antar variabel independen yang nilainya lebih dari $95 \%$.

Hasil perhitungan VIF juga menunjukkan hal yang sama tidak ada variabel independen yang memiliki nilai VIF lebih dari 10, jadi dapat disimpulka bahwa tidak ada multikolinieritas antara variabel independen dalam model regresi.

Pengujian heteroskedastisitas dilakukan dengan melihat grafik scatterplot seperti yang disajikan pada Gambar 1 di bawah ini. 
Gambar Scatterplot pada Gambar 1 tanda + ) satu nilai pada arus kas akan menunjukkan bahwa titik-titik menyebar memberikan kenaikan skor sebesar 0,131. secara acak serta tersebar baik di atas maupun di bawah angka 0 pada sumbu Y. Maka dari Nilai beta menunjukkan besarnya pengaruh variabel arus kas dengan variabel investasi, itu dapat disimpulkan bahwa tidak terjadi heteroskedastisitas pada model regresi.

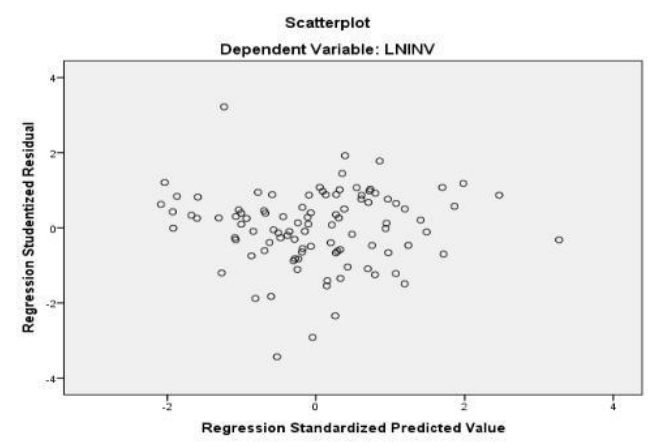
dimana dalam tabel di atas nilai Beta adalah 0,163. Hal ini menunjukkan bahwa besarnya pengaruh arus kas terhadap investasi sebesar 0,163 atau $16,3 \%$.

Hasil analisisi regresi modmed disajikan pada tabel 4 di bawah ini.

Tabel 4

\section{Gambar 1}

Hasil Uji Heteroskedastisitas

Sumber: Data Diolah Penulis, Tahun 2018

Hasil analisis regresi berganda penelitian ini disajikan pada Tabel 3 di bawah ini.

Tabel 3

Hasil Analisis Regresi Sederhana

\begin{tabular}{lrrr}
\hline & $\begin{array}{c}\text { Koefisien } \\
\text { Regresi }\end{array}$ & $\boldsymbol{\beta}$ & Sig. \\
\hline (Constant) & $-2,023$ & & 0,000 \\
Arus kas & 0,131 & 0,163 & 0,106 \\
\hline
\end{tabular}

Variabel dependen: investasi

Sumber: Data Diolah Penulis, Tahun 2018

Persamaan regresi investasi $=-2,023+$ 0,131 arus kas menyatakan bahwa jika tidak ada kenaikan nilai arus kas, nilai investasi adalah -2,023. Koefisien regresi sebesar 0,131 menyatakan bahwa setiap penambahan (karena 
Sri Rahmah Putri Bestari dan Kiswanto/ Jurnal Ilmiah Wahana Akuntansi, 14 (1) 2019, 33-48

Hasil output syntax modmed Pecking Order yang dikemukan oleh Myers menunjukkan berbagai nilai moderator dan (1984). besarnya pengaruh tidak langsung CSR. Jadi, dapat disimpulkan bahwa CSR terbukti menjadi moderator pengaruh arus kas terhadap investasi. Bagian dependen variabel model menjelaskan variabel mediator biaya agensi, variabel moderator CSR dan interaksi antara moderator dan mediator.

Uji regresi modmed menunjukkan hasil bahwa pengaruh variabel mediator biaya agensi terhadap variabel dependen investasi tergantung dari variabel moderator CSR dengan koefisien interaksi sebesar 2,2919.

Ringkasan hasil hipotesis dari penelitian ini disajikan pada Tabel 5 di bawah ini.

\section{Tabel 5}

\section{Ringkasan Hasil Uji Hipotesis}

\begin{tabular}{|c|c|c|c|c|}
\hline Hipotesis & Pernyataan & $\boldsymbol{\beta}$ & Sig. & Hasil \\
\hline $\mathrm{H}_{1}$ & $\begin{array}{l}\text { Arus kas } \\
\text { berpengaruh } \\
\text { positif terhadap } \\
\text { investasi }\end{array}$ & 0,163 & 0,106 & Ditolak \\
\hline $\mathrm{H}_{2}$ & $\begin{array}{l}\text { CSR memoderasi } \\
\text { pengaruh arus kas } \\
\text { terhadap investasi }\end{array}$ & 0,0035 & 0,7304 & Diterima \\
\hline $\mathrm{H}_{3}$ & $\begin{array}{l}\text { Biaya agensi } \\
\text { memediasi efek } \\
\text { moderat CSR }\end{array}$ & 2,2919 & 0,8277 & Diterima \\
\hline
\end{tabular}

Sumber: Data Diolah Penulis, Tahun 2018

\section{Pengaruh Arus Kas terhadap Investasi}

Hasil pengujian hipotesis menunjukkan bahwa $\mathrm{H}_{1}$ ditolak, sehingga arus kas tidak berpengaruh terhadap investasi. Hasil penelitian ini tidak sesuai dengan teori

Pecking Order Theory menggambarkan sebuah tingkatan dalam pencarian dana perusahaan yang menunjukkan bahwa perusahaan lebih memilih menggunakan internal equity dalam membiayai investasi dan mengimplementasikannya sebagai peluang pertumbuhan. Hal ini kemungkinan dikarenakan jumlah kas yang ada digunakan untuk pembagian dividen tunai pada para pemegang saham.

Sejalan dengan penelitian yang dilakukan oleh Atmawati (2013) yang membuktikan bahwa arus kas tidak berpengaruh terhadap investasi. Hal ini kemungkinan dikarenakan pada sampel penelitian ini mempunyai jumlah arus kas yang relatif kecil sehingga tidak dapat digunakan untuk mendanai kegiatan investasi bagi perusahaan. Hal ini didukung oleh hasil olah data statistik deskriptif yang menunjukkan bahwa arus kas memiliki nilai minimum yang minus yaitu sebesar 2370735,538. Oleh karena itu, jumlah arus kas tidak berpengaruh signifikan terhadap kesempatan investasi oleh perusahaan.

Selain itu, hasil ini didasari oleh kemungkinan bahwa jumlah dan kas yang tersedia dalam perusahaan digunakan untuk pembagian dividen tunai pada para pemegang saham, sehingga jumlah kas yang tersedia tidak mempengaruhi kesempatan investasi bagi perusahaan. 
Peran CSR dalam Memoderasi Pengaruh Arus Kas terhadap Investasi

Hasil pengujian hipotesis menunjukkan bahwa $\mathrm{H}_{2}$ diterima, sehingga dapat disimpulkan bahwa CSR dapat menjadi moderator hubungan arus kas terhadap investasi. Signalling theory yang diajukan sebagai grand theory dalam penelitian ini ternyata mampu menjelaskan pengungkapan Corporate Social Responsibility (CSR) dapat menjadi variabel moderasi hubungan antara arus kas terhadap investasi.

Signalling theory secara umum menyatakan bahwa perusahaan harus memberikan sinyal kepada pengguna laporan keuangan. Perusahaan melakukan pengungkapan Corporate Social Resonsibility (CSR) dengan harapan dapat meningkatkan reputasi dan nilai perusahaan di masa yang akan datang (Anggitasari, 2012).

Corporate Social Responsibility (CSR) dalam penelitian ini di ukur menggunakan jumlah item yang diungkapkan perusahaan dibagi dengan jumlah item pengungkapan berdasarkan Global Reporting Initiative (GRI). CSR adalah tanggung jawab sosial yang dilakukan secara sukarela oleh perusahaan terhadap lingkungan dan masyarakat serta pemerintah, bertujuan untuk meminimalkan dampak negatif yang timbul dari kegiatan operasional perusahaan dan memberikan kontribusi bagi pembangunan ekonomi berkelanjutan (Liu dan Irwansyah, 2016). Hal ini yang menjadi pertimbangan bahwa CSR dapat menjadi moderator hubungan antara arus dan investasi karena dengan nilai lingkungan yang baik akan dapat menarik minat investor untuk berinvestasi di perusahaan tersebut sehingga dana internal perusahaan tetap tersedia dan seimbang dengan pembiayaan eksternal perusahaan.

Hasil penelitian ini tidak sejalan dengan penelitian sebelumnya yang dilakukan oleh (Samet dan Jarboui, 2017) bahwa investasi kurang sensitif terhadap arus kas internal ketikan perusahaan memiliki tingkat kinerja CSR yang lebih tinggi. Cheng (2014) menemukan bahwa perusahaan dengan kinerja unggul dalam CSR memiliki akses yang lebih baik terhadap keuangan dan keterbatasan modal yang rendah.

\section{Pengaruh Biaya Agensi dalam Memediasi Efek Moderat CSR}

Hasil pengujian menunjukkan bahwa $\mathrm{H}_{3}$ diterima, sehingga dapat disimpulkan bahwa variabel biaya agensi dapat memediasi efek moderat CSR. Teori agensi yang diajukan sebagai grand theory dalam penelitian ini ternyata mampu menjelaskan biaya agensi mampu menjadi variabel mediasi efek moderat CSR. Secara umum teori agensi menjelaskan bahwa hubungan keagenan merupakan suatu kontrak dimana satu atau lebih orang (principal) memerintah orang lain (agen) untuk melakukan suatu jasa atas nama principal serta memberi wewenang kepada 
agen membuat keputusan yang terbaik bagi principal.

Biaya agensi dalam penelitian ini diukur melalui rasio pengeluaran biaya operasional terhadap penjualan (operating expense to sales ratio) yaitu perbedaan pengeluaran operasional perusahaan dengan zero agency costs denga perusahaan yang memiliki struktur kepemilikan tertentu. Pengukuran ini untuk mengetahui adanya kelebihan pengeluaran untuk keperluan non esensial (perquisite consumption). Operational expense to sales lebih tinggi menunjukkan adanya agency costs positif (Ade, 2008).

Jensen (1986) mengungkapkan ketika fungsi tujuan manajemen tidak mencerminkan kepentingan pemegang saham, inefisiensi investasi dapat terjadi karena konflik keagenan antara pemilik dan pemegang saham. Pandangan resolusi konflik menunjukkan bahwa investasi CSR dilakukan untuk menyelesaikan konflik diantara pemangku kepentingan. Ketika agen bertindak sesuai dengan kepentingan principal maka kemungkinan kecil terjadinya konflik keagenan.

Hubungan antara arus kas dan investasi ini dapat mengarah pada masalah asimetri informasi. Akibat adanya asimetri informasi ini dapat menimbulkan konflik keagenan antara manajemen dengan pemilik atau investor dikarenakan manajemen dapat bertindak untuk kepentingan pribadi dengan informasi yang dimilikinya. Konflik keagenan inilah yang nantinya akan mengakibatkan adanya biaya agensi atau agency costs. Oleh karena itu, faktor yang dapat mengurangi friksi tersebut dalam penelitian ini menggunakan CSR.

Hasil penelitian ini sejalan dengan penelitian yang dilakukan oleh (Samet dan Jarboui, 2017) bahwa dampak arus kas yang ditimbulkan CSR terhadap investasi mengikuti jalur melalui biaya agensi. Oleh karena itu, dengan tanggung jawab hukum manajer kepada pemangku kepentingan dan tanggung jawab etisnya terhadap masyarakat, perusahaan mengurangi biaya agensi, yang mengarah pada peningkatan hubungan dengan para pemangku kepentingan.

\section{KESIMPULAN DAN SARAN \\ Kesimpulan}

Hasil penelitian menunjukkan bahwa variabel arus kas tidak berpengaruh terhadap investasi. Namun, hasil penelitian menyimpulkan bahwa CSR mampu menjadi variabel moderator hubungan arus kas terhadap investasi dan biaya agensi mampu menjadi variabel mediasi efek moderat CSR.

\section{Saran}

Saran dari penelitian ini adalah perusahaan diharapkan dapat meningkatkan kemampuannya dalam menghasilkan kas yang positif, penelitian selanjutnya diharapkan menggunakan sampel perusahaan yang lain misal perusahaan pertambangan, perusahaan 
jasa, perusahaan keuangan, perusahaan properti dan lain sebagainya.

Selain itu, penelitian selanjutnya diharapkan menggunakan periode pengamatan yang lebih baru agar memperoleh hasil yang berbeda dari penelitian ini karena arus kas yang ada pada perusahaan periode tersebut relatif kecil sehingga tidak berpengaruh signifikan terhadap investasi.

\section{DAFTAR PUSTAKA}

Ade, Y. (2008). Hubungan Struktur Kepemilikan Dan External Monitoring Terhadap Agency Cost Dan Aliran Kas. Jurnal Keuangan Dan Perbankan, 12 (3), 343-354.

Akerlof,G.A (1970). The Market for "Lemons": Quality Uncertainty and the Market Mechanism. The Quarterly Journal of Economics. 84(3), 488-500.

Anggitasari, N. (2012). Pengaruh Kinerja Keuangan Terhadap Nilai Perusahaan Dengan Pengungkapan Corporate Social Responsibility Dan Struktur Good Corporate Governance Sebagai Variabel Pemoderasi. Diponegoro Journal of Accounting. 1, 1-74.

Astuti, A. D., Rahman, A. dan Sudarno. (2015). Pengaruh Kepemilikan Keluarga Terhadap Kinerja Perusahaan Dengan Agency Cost Sebagai Variabel Moderating. Jurnal Dinamika Akuntansi. 7(2), 1-11.

Atmawati, D. P. (2013). Pengaruh Cash Flow, Profitability, Dan Company Growth Terhadap Investment Opportunity Set: Pengujian Atas Perusahaan Non Keuangan Yang Terdaftar Di Bursa Efek Indonesia. Skripsi. Solo : Fakultas Ekonomi Universitas Sebelas Maret.
Beiting Cheng, I. I. dan G. S. (2014). Corporate Social Responsibility And Access To Finance. Strategic Management Journal. 35, 315-334.

Benardi, Jemmi. (2010). Pengaruh Cash Flow Terhadap Leverage dan Investasi serta Dampaknya Terhadap Nilai Perusahaan. Jurnal Ekonomi dan Kewirausahaan. 10 (2), 93-108.

Deny,Septian. (2017). Industri Manufaktur Jadi Solusi Beragam Masalah Ekonomi di RI. (diunduh tanggal 12 Maret 2018).

Fistyarini, R., \& Kusmuriyanto. (2015). Pengaruh Profitabilitas, IOS dan leverage terhadap Kebijakan Dividen Tunai Dimoderasi Likuiditas. Accounting Analysis Journal. 4(2), 361369.

Guizani, Moncef. (2017). Free Cash Flow, Agency Cost and Dividend Policy of Sharia- Compliant and Non-ShariaCompliant firms. International Journal of Economics and Management. 11(2), 355-370.

Hadianto, M. L. (2013). Analisis Pengaruh Kinerja Keuangan Terhadap Nilai Perusahaan Dengan Pengungkapan CSR Dan GCG Sebagai Variabel Pemoderasi. Skripsi. Semarang: Fakultas Ekonomi Universitas Diponegoro.

Haming, M., \& Basamalah, S. (2010). Studi Kelayakan Investasi Proyek \& Bisnis.

Hanifah, U., \& Khafid, M. (2016). The Analysis of Earnings Persistence Roles in Mediating The Effect of Operating Cash Flow and Debt Level on Stock Return. Accounting Analysis Journal. 5 (4), 290-298.

Harahap. Sofyan S. (2008). Analisis Kritis Atas Laporan Keuangan. Edisi Satu. Jakarta : PT Raja Grafindo Persada. 
Harian Neraca Ekonomi. (2018). Manufaktur Terbelit Masalah dari Segala Penjuru. (diunduh tanggal 12 Maret.2018).

Harjoto, M.A and Jo,H. (2011). Corporate goernance and CSR nexus. Journal of Business Ethics. 100(1), 45-67.

Herlina, Ade Dina, D. B. dan P. T. K. Pengaruh Free Cash Flow Terhadap Kinerja Perusahaan Melalui Agency Cost Sebagai Variabel Antara Pada Perusahaan Manufaktur Yang Terdaftar

Di Bursa Efek Indonesia. 1-16.

Janalis, Rawanda.(2015). Pengaruh Arus Kas Terhadap Investasi Pada Perusahaan Manufaktur Yang Terdaftar Di Bursa Efek Indonesia. Tesis. Banda Aceh:

Fakultas Ekonomi Universitas Syiah Kuala.

Jensen. Michael. (1986). Agency Costs of Free Cash Flow, Corporate Finance, and Takeovers. The American Economic Review. 76(2), 323-329.

Jensen, M. C., dan Meckling, W. H. (1976). Theory of the Firm: Managerial Behavior, Agency Costs and Ownership Structure. Journal of Financial Economics. 3(4), 305-360.

KH, Rahajeng dan Syukra,Ridho.(2017). 2017, Investasi Manufaktur Rp $400 \mathrm{~T}$. (diunduh tanggal 12 Maret 2018).

Liu, Alfini Maryanti dan Irwansyah, Z. F. (2016). Peran Agency Cost Reduction Dalam Memediasi Hubungan Antara Corporate Social Responsibility Dengan Nilai Perusahaan. Jurnal Ekonomi, Manajemen Dan Akuntansi. 18(2), 141156.

Matthias, Rudy dan Abraham,Allisha. (2001). The Impact Of Cash Flow On Corporate Investment In Trinidad And Tobago.
Masrurun, I., \& Yanto, H. (2015). Determinan Perilaku Investor Individu Dalam Pengambilan Keputusan Investasi. Accounting Analysis Journal. 4(4), 1-9.

Melander, O. (2009). The effect of cash flow on investment: An empirical test of the balance sheet channel (No. 228). Stockholm.

Munawaroh, A. (2014). Pengaruh Profitabilitas Terhadap Nilai Perusahaan dengan Corporate Social Responsibility Sebagai Variabel Moderating. Jurnal Ilmu Dan Riset Akuntansi. 3(4), 1-17.

Myers, Stewart C. (1984). The Capital Structure Puzzle Revisited. Journal of Finance. 39(3), 1-24.

Nandy, M and Lodh, S. (2012). Do banks value the eco-friendliness of firms in their corporate lending decision? Some empirical evidence. International Review of Financial Analysis. 25(1), 83-93.

Rahayuningsih, Dyah. (2013). Pengaruh Kesempatan Investasi, Konsentrasi Kepemilikan, Leverage, Komposisi Aktiva, Ukuran Perusahaan, Dan Faktor

Regulasi Terhadap Kualitas Good Corporate Governance. Jurnal Dinamika Akuntansi. 5(2), 135-145.

Samet, M., \& Jarboui, A. (2017). CSR, agency costs and investment -cash flow sensitivity: a mediated moderation analysis. Journal Managerial Finance. 43(3), 299-312.

Saragih, J. L. (2008). Faktor-Faktor Yang Mempengaruhi Keputusan Investasi Pada Perusahaan Barang Konsumsi Di Bursa Efek Indonesia. Tesis. Medan: Sekolah Pasca Sarjana Universitas Sumatera Utara.

Shamsuddini, H. dan G. A. (2017). The Influence Of Corporate Social Responsibility On The Relationship 
Sri Rahmah Putri Bestari dan Kiswanto/ Jurnal Ilmiah Wahana Akuntansi, 14 (1) 2019, 33-48

Between Agency Costs Of Free Cash

Flow And The Sensitivity Of Investment

To Cash Flow Of The Companies Listed

On Tehran Stock Exchange (TSE).

Tandelilin,Eduardus. (2010). Portofolio dan Investasi teori dari aplikasi. Edisi Pertama. Yogyakarta: BPFE.

Yocelyn, Azilia dan Yulius J.C. 2012." Analisis Pengaruh Perubahan Arus Kas Dan Laba Akuntansi Terhadap Return Saham pada Perusahaan Berkapitalisasi Besar". Jurnal Akuntansi dan Keuangan.14(2), 81-90.

Yuliawati, R. dan Sukriman. (2015). Faktorfaktor Yang Mempengaruhi Pengungkapan Corporate Social Responsibility. Accounting Analysis Journal. 4(4), 1-9. 
Sri Rahmah Putri Bestari dan Kiswanto/ Jurnal Ilmiah Wahana Akuntansi, 14 (1) 2019, 33-48

\section{Lampiran 1: Definisi Operasional dan LamiranPengukuran Variabel}

\begin{tabular}{|c|c|c|c|}
\hline No & Variabel & Definisi Variabel & Indikator Pengukuran \\
\hline 1. & Investasi & $\begin{array}{l}\text { Investasi adalah komitmen atas jumlah } \\
\text { dana atau sumber daya lainnya yang } \\
\text { dilakukan pada saat ini, dengan tujuan } \\
\text { memperoleh sejumlah keuntungan di masa } \\
\text { Datang } \\
\text { (Eduardus Tandelilin,2010) }\end{array}$ & $\begin{array}{l}\text { a. Total aset tahun } \\
\text { berjalan } \\
\text { b. Total asel tahun } \\
\text { sebelumnya (Saragih } \\
\text { 2008) }\end{array}$ \\
\hline 2. & Arus kas & $\begin{array}{l}\text { Laporan arus kas adalah suatu laporan yang } \\
\text { bertujuan untuk memberikan informasi } \\
\text { yang relevan tentang penerimaan dan } \\
\text { pengeluaran kas atau setara kas dari suatu } \\
\text { perusahaan pada suatu periode tertentu } \\
\text { (Harahap, 2008) }\end{array}$ & $\begin{array}{l}\text { a. Arus kas aktivitas } \\
\text { operasi } \\
\text { b. Arus kas aktivitas } \\
\text { investasi } \\
\text { c. Arus kas aktivitas } \\
\text { pendanaan (Yocelyn } \\
\text { dan Christiawan } \\
\text { 2012) }\end{array}$ \\
\hline 3. & CSR & $\begin{array}{l}\text { CSR adalah tanggung jawab sosial yang } \\
\text { dilakukan secara sukarela oleh perusahaan } \\
\text { terhadap lingkungan dan masyarakat serta } \\
\text { pemerintah, bertujuan untuk meminimalkan } \\
\text { dampak negatif yang timbul dari kegiatan } \\
\text { operasional perusahaan dan memberikan } \\
\text { kontribusi bagi pembangunan ekonomi } \\
\text { Berkelanjutan } \\
\text { (Liu dan Irwansyah, 2016) }\end{array}$ & $\begin{array}{ll}\text { a. } & \text { Jumlah item yang } \\
& \text { diungkapkan } \\
\text { perusahaan } & \\
\text { b. } & \text { Jumlah item } \\
\text { pengungkapan } \\
\text { berdasarkan GRI } \\
\text { (Hadianto 2013) }\end{array}$ \\
\hline 4. & $\begin{array}{l}\text { Biaya } \\
\text { Agensi }\end{array}$ & $\begin{array}{l}\text { Biaya keagenan merupakan biaya yang } \\
\text { dikeluarkan perusahaan untuk mencapai } \\
\text { titik temu atas perbedaan kepentingan } \\
\text { antara agen dan principal } \\
\text { (Hendro dan Ratna, 2015) }\end{array}$ & $\begin{array}{l}\text { a. Operating expense } \\
\text { b. Net sales (Ade, Y. } \\
\text { 2008) }\end{array}$ \\
\hline
\end{tabular}

